Atmos. Chem. Phys. Discuss., https://doi.org/10.5194/acp-2017-596

Manuscript under review for journal Atmos. Chem. Phys.

Discussion started: 1 August 2017

(c) Author(s) 2017. CC BY 4.0 License.

\title{
Resolving ozone vertical gradients in air quality models
}

Katherine R. Travis ${ }^{1}$, Daniel J. Jacob ${ }^{1,2}$, Christoph A. Keller ${ }^{3,4}$, Shi Kuang ${ }^{5}$, Jintai Lin ${ }^{6}$, Michael J. Newchurch $^{7}$, Anne M. Thompson ${ }^{8}$

${ }^{1}$ School of Engineering and Applied Sciences, Harvard University, Cambridge, MA, USA

$5{ }^{2}$ Department of Earth and Planetary Sciences, Harvard University, Cambridge, MA, USA

${ }^{3}$ Universities Space Research Association, Columbia, MD, USA

${ }^{4}$ NASA Goddard Space Flight Center, Greenbelt, MD, USA

${ }^{5}$ Earth System Science Center, University of Alabama in Huntsville, Huntsville, AL 35805, USA

${ }^{6}$ Laboratory for Climate and Ocean-Atmosphere Studies, Department of Atmospheric and Oceanic Sciences, School of Physics,

10 Peking University, Beijing 100871, China

${ }^{7}$ Atmospheric Science Department, University of Alabama in Huntsville, Huntsville, AL 35805, USA

${ }^{8}$ Earth Science Division, NASA Goddard Space Flight Center, Greenbelt, MD 20771, USA

Correspondence to: Katherine R. Travis (ktravis@ fas.harvard.edu)

Abstract. Models severely overestimate surface ozone in the Southeast US during summertime and this overestimation has

15 implications for the design of air quality regulations. We use the GEOS-Chem model to interpret ozone observations from aircraft (SEAC ${ }^{4} \mathrm{RS}$ ), ozonesondes (SEACIONS), and surface sites (CASTNET) in August-September 2013. After correcting for a 30-50 $\% \mathrm{NO}_{\mathrm{x}}$ emission overestimate in the US EPA National Emission Inventory, we find that the model is unbiased relative to aircraft observations below $1 \mathrm{~km}$. However, surface observations of maximum daily 8-h average (MDA8) ozone are still biased high in the model (averaging $48 \pm 9 \mathrm{ppb}$ ) compared to observations ( $40 \pm 9 \mathrm{ppb}$ ). The low tail in the observations (MDA8 ozone < $25 \mathrm{ppb})$

20 is associated with rain and is not captured by the model. The model bias decreases by 3 ppb when accounting for the subgrid vertical gradient between the lowest model level (centered $60 \mathrm{~m}$ above ground) and the measurement altitude (10 m). The model underestimates low cloud cover, but this underestimate is insufficient to explain the remaining surface ozone bias because the response of model ozone to cloud cover is weaker than observed. Midday ozonesondes at Huntsville, Alabama show mean decreases in ozone from $1 \mathrm{~km}$ to the surface of $4 \mathrm{ppb}$ under clear-sky and $7 \mathrm{ppb}$ under low cloud, whereas the model decreases by

25 only $1 \mathrm{ppb}$ under both conditions. By contrast, potential temperature below $1 \mathrm{~km}$ is well-mixed in both the observations and the model. The observations thus imply a strong asymmetry between top-down and bottom-up mixing that is missing from GEOSChem and appears to be insufficiently represented in current air quality models. A sensitivity simulation reducing top-down eddy diffusion and removing top-down non-local vertical transport of ozone can reproduce the observed ozone gradients in the mixed layer.

\section{$30 \quad 1$ Introduction}

Ground-level ozone is harmful to human health and vegetation. Ozone is produced in the troposphere when volatile organic compounds (VOCs) and carbon monoxide (CO) are photochemically oxidized in the presence of nitrogen oxide radicals $\left(\mathrm{NO}_{\mathrm{x}} \equiv\right.$ $\mathrm{NO}+\mathrm{NO}_{2}$ ). Natural sources of VOCs, $\mathrm{CO}$, and $\mathrm{NO}_{\mathrm{x}}$ from the biosphere, wildfires, and lightning contribute an ozone background. Anthropogenic sources, mainly from fuel combustion, increase ozone levels. The chemistry involved is complex and non-linear.

35 Air pollution control strategies rely on chemical transport models (CTMs) to identify the most effective emission reductions, but confidence in these models can be limited by their inability to reproduce ozone observations. The Southeast US in summer is a particularly problematic region, as models tend to greatly overestimate surface ozone levels (Lin et al., 2008; Fiore et al., 2009; Reidmiller et al., 2009; Chai et al., 2013; Brown-Steiner et al., 2015; Canty et al., 2015; Travis et al., 2016; Lin et al., 2017). An 
Atmos. Chem. Phys. Discuss., https://doi.org/10.5194/acp-2017-596

Manuscript under review for journal Atmos. Chem. Phys.

Discussion started: 1 August 2017

(c) Author(s) 2017. CC BY 4.0 License.

intercomparison of 21 models by Fiore et al. (2009) showed an average overestimate of $25 \mathrm{ppb}$ in the Southeast in August. Here we use a combination of aircraft, ozonesonde, and surface observations in summer 2013 to better understand this overestimate and draw general insights for ozone air quality modeling.

5 The Southeast US in summer is characterized by relatively high $\mathrm{NO}_{\mathrm{x}}$ emissions, very high emissions of biogenic isoprene, strong insolation, and frequent regional stagnation, all conditions favorable for producing elevated ozone. A range of explanations have been proposed for the model overestimates of ozone in that region including excessive ozone background over the Gulf of Mexico (Fiore et al., 2003), uncertainty in isoprene emissions and chemistry (Fiore et al., 2005; Horowitz et al., 2007; Squire et al., 2015), insufficient ozone dry deposition (Lin et al., 2008), missing halogen chemistry (McDonald-Buller et al., 2011), and excessive $\mathrm{NO}_{\mathrm{x}}$

10 emissions in current inventories (Travis et al., 2016).

Detailed probing of the chemical environment of the Southeast US took place in summer 2013 with surface and aircraft observations from the Southeast Atmosphere Studies (SAS) in June-July (Carlton et al., 2016), the NASA SEAC ${ }^{4}$ RS aircraft campaign in August-September (Toon et al., 2016), and the SEACIONS ozonesonde network

15 (https://tropo.gsfc.nasa.gov/seacions/), adding to the long-term ozone air quality monitoring network. In previous work by Travis et al. (2016), we applied the GEOS-Chem CTM at $0.25^{\circ} \times 0.3125^{\circ}$ spatial resolution to the simulation of SEAC ${ }^{4}$ RS observations. The standard model overestimated ozone by $12 \mathrm{ppb}$ below $1.5 \mathrm{~km}$ altitude. On the basis of observations of $\mathrm{NO}_{\mathrm{x}}$ and its oxidation products, together with national nitrate wet deposition data, we showed that the $\mathrm{NO}_{\mathrm{x}}$ National Emission Inventory (NEI) from the US Environmental Agency (EPA, 2015) was too high by 30-50\%. This finding was subsequently supported by SAS observations

20 (Miller et al., 2017). Previous studies had documented such a $\mathrm{NO}_{\mathrm{x}} \mathrm{NEI}$ bias in urban areas (Fujita et al., 2012; Yu et al., 2012; Brioude et al., 2013; Anderson et al., 2014), but our results suggest that the bias is national in extent. After correcting this $\mathrm{NO}_{\mathrm{x}}$ emission overestimate in GEOS-Chem, we found that we could match the SEAC ${ }^{4} \mathrm{RS}$ aircraft observations below $1.5 \mathrm{~km}$ altitude, but the model mean bias against surface network observations was still $6 \pm 14 \mathrm{ppb}$. Midday ozonesonde observations showed an increase of ozone with altitude in the lowest $1 \mathrm{~km}$ of the atmosphere that the model failed to capture. Here we examine the origin of this ozone vertical gradient and the implications for modeling surface ozone.

\section{GEOS-Chem simulation}

The GEOS-Chem simulation used here is as described by Travis et al. (2016). It is based on GEOS-Chem version 9.02 with detailed oxidant-aerosol chemistry (www.geos-chem.org) and is driven by assimilated meteorological data from the Goddard Earth Observing System - Forward Processing (GEOS-FP) product of the NASA Global Modeling and Assimilation Office (GMAO)

30 using the GEOS-5.11.0 general circulation model (GCM). The GEOS-FP data have a native horizontal resolution of $0.25^{\circ}$ latitude by $0.3125^{\circ}$ longitude, with 72 levels in the vertical and a temporal resolution of $3 \mathrm{~h}$ ( $1 \mathrm{~h}$ for surface variables and mixing depths). This native $0.25^{\circ} \times 0.3125^{\circ}$ horizontal resolution is used in GEOS-Chem over North America and adjacent oceans $\left(130^{\circ}-60^{\circ} \mathrm{W}\right.$, $9.75^{\circ}-60^{\circ} \mathrm{N}$ ), with boundary conditions from a global simulation with $4^{\circ} \times 5^{\circ}$ horizontal resolution.

35 The model representations of planetary boundary layer (PBL) mixing and ozone deposition are particularly relevant for this work. The PBL is defined as the column of air in contact with the surface on a daily basis. Observations show that the PBL over the Southeast US in summer extends to 1-3 km altitude and is capped by a semi-permanent subsidence inversion (Toon et al., 2016). Within the PBL, the unstable mixed layer driven by surface heating rises rapidly in the morning to reach a maximum altitude 
Atmos. Chem. Phys. Discuss., https://doi.org/10.5194/acp-2017-596

Manuscript under review for journal Atmos. Chem. Phys.

Discussion started: 1 August 2017

(c) Author(s) 2017. CC BY 4.0 License.

(mixing depth) of $1.7 \pm 0.4 \mathrm{~km}$ by afternoon, as observed in SEAC ${ }^{4} \mathrm{RS}$ by aerosol lidar (Zhu et al., 2016), before collapsing in the evening. The afternoon mixed layer is often capped by shallow fair-weather cumuli (cloud convective layer) constituting the upper part of the PBL. The PBL is resolved in the GEOS-FP data (and hence in GEOS-Chem) by 18 vertical levels below $3 \mathrm{~km}$, and 8 below $1 \mathrm{~km}$ of approximately equal thickness. The lowest level is centered at $60 \mathrm{~m}$ above ground. Turbulence in the mixed layer

5 follows a clear-sky non-local parameterization from Holtslag and Boville (1993), as implemented in GEOS-Chem by Lin and McElroy (2010). The parameterization uses mixing depths from the GEOS-FP data, which are diagnosed as the GCM model level above which the eddy diffusivity for heat $\left(K_{h}\right)$ falls below a threshold value of $2 \mathrm{~m}^{2} \mathrm{~s}^{-1}$ (McGrath-Spangler and Molod, 2014). GEOS-FP mixing depths were found to be $40 \%$ too high compared to the SEAC ${ }^{4} \mathrm{RS}$ aerosol lidar data and this was corrected in the GEOS-Chem simulations (Zhu et al., 2016). Additional turbulence due to cloud cooling at the PBL top is included in the GEOS-

10 5.11.0 GCM following Lock et al. (2000) but not in the Holtslag and Boville (1993) scheme.

Ozone deposition in GEOS-Chem follows the resistance-in-series scheme of Wesely (1989) as implemented by Wang et al. (1998) and further modified for SEAC ${ }^{4}$ RS conditions by Travis et al. (2016). The mean daytime (09:00-16:00 local) ozone deposition velocity over the Southeast US in the model is $0.7 \pm 0.3 \mathrm{~cm} \mathrm{~s}^{-1}$ during August-September 2013. Comparison with ozone deposition

15 measurements by Finkelstein et al. (2000) at Duke Forest, North Carolina shows good agreement with a mean ozone deposition velocity of $0.8 \mathrm{~cm} \mathrm{~s}^{-1}$ during daytime. Aircraft eddy covariance flux measurements over the Ozarks forest during SEAC ${ }^{4} \mathrm{RS}$ indicate a daytime ozone deposition velocity of $0.8 \pm 0.1 \mathrm{~cm} \mathrm{~s}^{-1}$, in agreement with the local GEOS-Chem value of $0.9 \mathrm{~cm} \mathrm{~s}^{-1}$ (Wolfe et al., 2015).

20 Detailed evaluations of GEOS-Chem with SAS and SEAC ${ }^{4} \mathrm{RS}$ observations have been reported in previous studies. Initial evaluations led to corrections of daytime mixing depths (Zhu et al., 2016), NEI NO $\mathrm{x}_{\mathrm{x}}$ emissions (Travis et al., 2016), and isoprene chemistry (Fisher et al., 2016; Travis et al., 2016). After these corrections, the model was found to be successful in reproducing surface and aircraft observations of aerosol composition (Kim et al., 2015b; Marais et al., 2016) and organic nitrates (Fisher et al., 2016), and aircraft observations of formaldehyde (Zhu et al., 2016), glyoxal (Miller et al., 2017), and ozone and its precursors

25 (Travis et al., 2016; Yu et al., 2016). Travis et al. (2016) presented model comparisons to observations of (1) $\mathrm{NO}_{\mathrm{x}}$, (2) the relationship of ozone to $\mathrm{NO}_{\mathrm{x}}$ oxidation products (a measure of the ozone production efficiency), and (3) isoprene nitrates and peroxides tracking the high-NO (ozone-producing) and low-NO pathways for isoprene oxidation. This evaluation lends some confidence in the model simulation of ozone chemistry.

\section{Ozone frequency distributions in the mixed layer and surface air}

30 Figure 1 (left panel) shows the frequency distribution of afternoon (12-18 local time) ozone concentrations in August-September 2013 measured by the SEAC ${ }^{4} \mathrm{RS}$ DC-8 aircraft in the mixed layer at 0.4-1.0 km altitude. The mean ozone in the mixed layer as measured by the aircraft is $50 \pm 10 \mathrm{ppb}$. The model sampled along the aircraft tracks is in good agreement ( $52 \pm 10 \mathrm{ppb}, r=0.54)$. The model does not capture the observed extremes and this can be simply explained by numerical diffusion (Yu et al., 2016). In particular, observations above 75 ppb are associated with urban (Houston) and agricultural fire plumes (Travis et al., 2016).

35

Also shown in Figure 1 (right panel) is the frequency distribution of maximum daily 8-hour average (MDA8) ozone at the CASTNET surface network for the same period (https://www.epa.gov/castnet). CASTNET monitors air quality in rural areas and is therefore representative of regional air quality. The mean MDA8 ozone measured at CASTNET sites is $40 \pm 9 \mathrm{ppb}$, while the 
Atmos. Chem. Phys. Discuss., https://doi.org/10.5194/acp-2017-596

Manuscript under review for journal Atmos. Chem. Phys.

Discussion started: 1 August 2017

(c) Author(s) 2017. CC BY 4.0 License.

(c) (i)

corresponding model mean is $48 \pm 9 \mathrm{ppb}$, for a high mean bias of $8 \pm 9 \mathrm{ppb}$. The model shows only a $4 \mathrm{ppb}$ difference between the mixed layer sampled by the aircraft and the surface, but the observations imply a 10 ppb difference.

Part of the surface bias in the model can be simply attributed to representation error. The lowest model grid-point in GEOS-Chem

5 is centered at $60 \mathrm{~m}$ above the local surface. The CASTNET measurements are typically at $10 \mathrm{~m}$ altitude. Implicit model ozone concentrations at $10 \mathrm{~m}$ can be inferred from the values at $60 \mathrm{~m}$ and the local ozone deposition velocity by applying the model aerodynamic resistance $\left(R_{a}\right)$ between 60 and $10 \mathrm{~m}$. The formula for this correction is presented in Zhang et al. (2012). We combine a typical friction velocity $u^{*}=0.4 \mathrm{~cm} \mathrm{~s}^{-1}$, daytime Monin-Obhukov length $|L|=40 \mathrm{~m}$, and $R_{a}=0.07 \mathrm{~s} \mathrm{~cm}^{-1}$ with an ozone deposition velocity of $0.8 \mathrm{~cm} \mathrm{~s}^{-1}$ and find an average ozone decrease of $3 \mathrm{ppb}$ between $60 \mathrm{~m}$ and $10 \mathrm{~m}$. The right panel of Figure 1 includes

10 the implied model pdf at $10 \mathrm{~m}$ altitude, as inferred from the local model values of $R_{a}$; the model mean is $45 \pm 8$ ppb. The mean bias relative to observations decreases to $5 \pm 9 \mathrm{ppb}$. We apply this correction in all following model comparisons.

The relatively low surface ozone measured at CASTNET sites in August-September 2013 reflects lower-than-average but not anomalous conditions. Figure 2 (top panel) shows the long-term trend of August-September MDA8 ozone in the Southeast US

15 from 1987 to 2015 . There is a $0.4 \mathrm{ppb} \mathrm{a}^{-1}$ decrease due to emission controls (Cooper et al., 2012). The 2013 data are 2 ppb below the linear fit to that long-term trend, and this may be due to cooler and wetter conditions than average (bottom panel).

The frequency distribution of MDA8 ozone at the CASTNET sites in Figure 1 shows a population of very low ozone concentrations below $25 \mathrm{ppb}$ that the model does not capture at all. Previous work has suggested that this population could be due to tropical air

20 transported from the Gulf of Mexico (Fiore et al., 2002; McDonald-Buller et al., 2011). However, we find that the observed occurrence of low values is distributed across the Southeast and is not related to distance from the Gulf. Four SEAC ${ }^{4} \mathrm{RS}$ flights sampled air over the Gulf of Mexico and showed a median ozone concentration of $26 \mathrm{ppb}$ below $1.5 \mathrm{~km}$ with the model in close agreement (Travis et al., 2016). Rain may be an additional factor driving low ozone, as discussed below.

\section{Relationship to cloud cover and precipitation}

25 We examined whether the $5 \pm 9$ ppb mean model bias in simulating MDA8 ozone at surface sites could be attributed to cloudy and rainy conditions. Such a bias would not affect the comparison to aircraft observations, which generally targeted clear-sky conditions. For this purpose we segregated the frequency distributions of ozone at CASTNET sites between clear-sky, low-cloud with no rain, and rainy days. Low cloud in the observations was diagnosed by 20-minute averaged data at nearby airports from the automated surface observing system network (ASOS) sensors collected by the Iowa Environmental Mesonet (IEM) with 371

30 locations in the Southeast US (http://mesonet.agron.iastate.edu/request/download.phtml). Cloud data below $680 \mathrm{hPa}$ are reported in oktas. Low-cloud conditions are defined here as average daytime cloud fraction greater than 3 oktas (3/8 cloud fraction), excluding rainy conditions, and clear-sky conditions are defined as less than 0.5 oktas ( $0.5 / 8$ cloud fraction). Rainy conditions are defined by daily average rainfall exceeding $6 \mathrm{~mm}$ in the PRISM data regridded to $0.25^{\circ} \times 0.3125^{\circ}$. Rainy conditions in the model are diagnosed in the same way as in the observations, while cloudy conditions are diagnosed from cloud fractions at different 
Atmos. Chem. Phys. Discuss., https://doi.org/10.5194/acp-2017-596

Manuscript under review for journal Atmos. Chem. Phys.

Discussion started: 1 August 2017

(c) Author(s) 2017. CC BY 4.0 License.

(c) (i)

vertical levels below $680 \mathrm{hPa}$ using the maximum random overlap scheme (MRAN) of Liu et al. (2006). In the remainder of this paper, "cloudy" conditions refer to low-cloud conditions.

Figure 3 shows the segregated pdfs of surface ozone in the observations and the model. The days for a given sky condition are not

5 necessarily the same in the observations and the model. We see that ozone decreases from clear to low-cloud to rainy conditions in both the observations and the model. The model is heavily biased toward clear-sky. The average daytime low-cloud cover across the entire Southeast is $32 \pm 9 \%$ from the ASOS sensors but only $7 \pm 3 \%$ in the GEOS-FP data. The GEOS-5 GCM underlying the GEOS-FP data uses a critical RH to trigger cloud formation (Molod et al., 2012; Molod et al., 2015) and the cloud bias could result from the setting of this trigger (Naud et al., 2010). The low-cloud bias in GEOS-FP is also apparent in comparison to satellite

10 observations from the Clouds and the Earth's Radiant Energy System (CERES) instruments (Minnis et al., 1995; Minnis et al., 2011). Figure 4 compares CERES low-cloud fractions in August-September 2013 in the Southeast with GEOS-FP values. The mean observed low-cloud fraction is $21 \pm 4 \%$ as compared to $9 \pm 2 \%$ in GEOS-FP. The mean in-cloud optical depth is $45 \pm 3$ in both CERES and GEOS-FP. Thus the optical depth of low clouds in GEOS-FP is consistent with observations but the cloud frequency is too small. Table 1 shows that the underestimate in GEOS-FP cloud fraction is mainly due to a lack of fair-weather

15 cumulus. Climate models generally tend to underestimate low cloud cover (Zhang, 2005; Mueller et al., 2006; Chepfer et al., 2008; Naud et al., 2010; Kay et al., 2012; Nam et al., 2012). The GEOS-Chem underestimate of sulfate aerosol production in SEAC ${ }^{4}$ RS, previously attributed by Kim et al. (2015) to a missing $\mathrm{SO}_{2}$ oxidation pathway involving Criegee biradicals, could instead be due to insufficient cloud processing.

20 We see from Figure 3 that the mean bias between model and observed surface ozone vanishes when only clear-sky conditions are considered, but persists under low-cloud and rainy conditions. Thus the bias cannot be simply attributed to insufficient cloud in the model. If we apply the observed frequencies of clear-sky, cloudy, and rainy days from Figure 3 to the model mean ozone concentrations for each category, we decrease the mean model MDA8 ozone bias at CASTNET sites by only 1 ppb. This is because of the weaker response in the model to cloud cover and rain (4 ppb relative to clear-sky) than observed (7 ppb and $11 \mathrm{ppb}$

25 respectively). Kim et al. (2015a) previously observed a 1 ppb decrease in ozone per $10 \%$ increase in cloud cover over the contiguous United States, and found that their model response to cloud (from the NOAA National Air Quality Forecast) was approximately half that, a similar bias to our model. We conducted a model sensitivity study with the low cloud fraction adjusted to the mean observed value of $32 \%$ from the ASOS observations. This simulation perturbs model photolysis but does not modify other meteorological variables. We find an ozone decrease of only $1 \mathrm{ppb}$ and thus photolysis appears to be only a minor effect.

30 Previous urban-scale model studies have found larger cloud effects on surface ozone from changes in photolysis (Pour-Biazar et al., 2007; Tang et al., 2015), but larger-scale studies find a weaker effect consistent with our findings (Voulgarakis et al., 2009). SEAC ${ }^{4} \mathrm{RS}$ observations of actinic fluxes in SEAC ${ }^{4} \mathrm{RS}$ show cloud effects consistent with radiative transfer models (Ryu et al., 2017).

35 The largest difference between model and observations occurs on rainy days. Rainy days account for over half of all days with observed MDA8 ozone below $25 \mathrm{ppb}$. Thus, the inability of the model to reproduce the low tail in the observed ozone distribution appears to be due in large part to positive bias on rainy days. This could reflect vertical stratification from surface evaporative cooling that is not properly captured in the model. The effect of precipitation on ozone through wet scavenging is negligible. 
Atmos. Chem. Phys. Discuss., https://doi.org/10.5194/acp-2017-596

Manuscript under review for journal Atmos. Chem. Phys.

Discussion started: 1 August 2017

(c) Author(s) 2017. CC BY 4.0 License.

Rainfall or dew may also enhance the non-stomatal component of ozone dry deposition (Finkelstein et al., 2000; Altimir et al., 2006; Potier et al., 2017) but the mechanism for this enhancement is uncertain and is not included in the model.

\section{Ozone vertical profiles at Huntsville}

The analysis above suggests that insufficient model response to cloud conditions and rain could be the cause of the remaining

5 surface ozone bias. We examined whether this could be related to excessive vertical mixing in the model by using the SEACIONS ozonesonde data from Huntsville, Alabama (31 launches at 10-13 local time during August-September 2013; https://tropo.gsfc.nasa.gov/seacions/). The ozonesondes measure ozone at approximately 5-m resolution from the surface through the stratosphere but the 5-m resolution data are averaged and reported at coarser resolution to achieve reasonable noise statistics. We interpolate the data to the model vertical resolution (approximately $130 \mathrm{~m}$ ) and down to $10 \mathrm{~m}$ above ground. Huntsville is a

10 small-sized city at 200-m ASL with forested land cover and little topography, and the ozonesonde data can be viewed as regionally representative (Newchurch et al., 2003).

The top panel of Figure 5 compares the time series of ozonesonde observations at Huntsville up to $12 \mathrm{~km}$ altitude to the corresponding GEOS-Chem values. The model successfully captures the large-scale features in the free troposphere above $3 \mathrm{~km}$

15 with no significant bias $(1 \pm 14 \mathrm{ppb})$. A comparison of the modeled and observed mean profile at Huntsville is shown in Travis et al. (2016).

The bottom panel of Figure 5 shows the ozonesonde vertical profiles with more resolution below $3 \mathrm{~km}$. As for the CASTNET data, we infer model ozone at $10 \mathrm{~m}$ for each ozonesonde launch from the simulated concentration at the lowest model level (60 m) and

20 local values of the aerodynamic resistance and ozone deposition flux. For the ensemble of ozonesonde launches, we find a mean $10-60 \mathrm{~m}$ aerodynamic resistance of $0.04 \mathrm{~s} \mathrm{~cm}^{-1}$ and an ozone deposition velocity of $0.8 \mathrm{~cm} \mathrm{~s}^{-1}$, resulting in a mean model difference of $1.6 \pm 0.5 \mathrm{ppb}$ ozone between 60 and $10 \mathrm{~m}$. This is less than the mean $3 \mathrm{ppb}$ effect found for MDA8 ozone at CASTNET sites (Section 3), because the MDA8 8-h averaging window includes periods with greater stability than midday. The implied model gradient at Huntsville is consistent with the mean observed difference of $0.7 \pm 0.9 \mathrm{ppb}$ in the ozonesonde data between 60 and 10 $25 \mathrm{~m}$.

We find that surface $(10 \mathrm{~m})$ ozone at Huntsville shows similar behavior to the CASTNET network. Mean observed surface ozone from the ozonesondes ( $43 \pm 12 \mathrm{ppb}$ ) compares well with the observed CASTNET MDA8 ozone shown in Figure 1. Ozone is lowest on rainy days ( $n=6,36 \pm 12 \mathrm{ppb}$ ), diagnosed from the PRISM data, similar to our finding at CASTNET sites in Figure 3 . The

30 lowest ozone (18 ppb) on September 21 occurred on the day with the most rainfall in the time series (50 mm), in air originating from the Gulf of Mexico. We do not find a significant difference in surface ozone at Huntsville between cloudy conditions ( $n=14$, $43 \pm 13 \mathrm{ppb})$ and clear conditions $(n=5,44 \pm 13 \mathrm{ppb})$, but this may be due to the small sample size. The modeled surface ozone for the ozonesonde launches is $48 \pm 9 \mathrm{ppb}$ and the mean model bias is $5 \pm 9 \mathrm{ppb}(r=0.67)$, same as at the CASTNET sites.

35 The mean ozone decrease from $1 \mathrm{~km}$ down to the surface is steeper in the observations $(6 \pm 5 \mathrm{ppb})$ than in GEOS-Chem ( $1 \pm 3$ $\mathrm{ppb}$ ) and agrees well with the implied gradient shown in Figure 1 between the SEAC ${ }^{4} \mathrm{RS}$ aircraft and CASTNET surface observations. The mean observed decrease is $4 \pm 5 \mathrm{ppb}$ on clear days $(n=5)$ and $7 \pm 6 \mathrm{ppb}$ on cloudy days $(n=14)$ but this difference is not statistically significant $(p=0.2)$. The model decrease is less than $1 \mathrm{ppb}$ on either clear $(n=15)$ or cloudy $(n=3)$ days. This 
Atmos. Chem. Phys. Discuss., https://doi.org/10.5194/acp-2017-596

Manuscript under review for journal Atmos. Chem. Phys.

Discussion started: 1 August 2017

(c) Author(s) 2017. CC BY 4.0 License.

(c) (i)

confirms that the model overestimate of surface ozone is due to underestimate of the gradient in the lowest km, particularly under cloudy conditions but also under clear-sky conditions.

\section{Top-down PBL mixing of ozone}

Figure 6 shows ozone and potential temperature profiles on two typical days where model and observations agree on the clear and

5 low-cloud classification. These specific days have free tropospheric biases but our interest here is in the simulation of the PBL vertical gradient. On the clear-sky day (Sep 4), the model is well-mixed throughout the lowest km but the observations show a vertical gradient, particularly in the lowest $300 \mathrm{~m}$. The potential temperature profile is well-mixed in both the observations and model. On the cloudy day (Aug 16) there is a steady gradient below $1 \mathrm{~km}$ in the observations that the model does not reproduce. The grey shading on Figure 6 shows the convective cloud layer in the upper part of the PBL and again the model does not capture

10 the gradient in that layer. We conducted a sensitivity on-line simulation in the GEOS-5 GCM using the GEOS-Chem chemical module (Long et al., 2015) and including the GEOS-5 PBL mixing scheme of Lock et al. (2000), but found the same excessive downward mixing of ozone as in the off-line GEOS-Chem. The inconsistency between potential temperature, which is well-mixed in both the observations and the model, and ozone, for which the observations show a vertical gradient absent from the model, suggests a bottom-up vs. top-down asymmetry in vertical mixing that is missing from both the Holtslag and Boville (1993) and

15 Lock et al. (2000) PBL schemes.

Wyngaard and Brost (1984) used large-eddy simulations to investigate top-down vs. bottom-up differences in eddy diffusion parameterizations of PBL mixing. They show that eddy diffusion coefficients $\left(K_{z}\right)$ for top-down transport should be about $60 \%$ lower than for bottom-up transport, due to the role of surface-driven buoyant plumes in contributing to bottom-up transport.

20 Additional non-local vertical transport in PBL schemes, developed originally for heat flux, is mostly intended to resolve buoyant plumes (Deardorff, 1966; Holtslag and Moeng, 1991) and should be formulated differently for top-down transport (Xie and Fung, 2014). We conducted a sensitivity simulation for the two sample days of Figure 6 where the Holtslag and Boville (1993) mixing scheme was modified for ozone to decrease $K_{z}$ by $60 \%$ and remove the non-local term. As shown in Figure 6 , this fully corrects the ozone gradient.

25

The need for asymmetric top-down vs. bottom-up PBL mixing for air quality applications has long been recognized (Pleim and Chang, 1992), and is presently implemented in the EPA Community Multiscale Air Quality (CMAQ) and in the Comprehensive Air Quality Model with Extensions (CAMx) using the Asymmetrical Convection Model version 2 (ACM2) (Pleim, 2007a, b). The ACM2 has the same eddy diffusion component as Holtslag and Boville (1993) but a different form of non-local parameterization.

30 It treats upward convective transport with a non-local buoyant component, but downward transport as a slower, layer-by-layer process. However, comparisons to ozonesonde and aircraft observations suggest that ACM2 still has excessive mixing for ozone down to the surface (Tang et al., 2011, Goldberg, 2015).

\section{Conclusions}

Models overestimate summertime surface ozone in the Southeast US. We showed previously using the GEOS-Chem model that

35 this overestimate is due in part to an overestimate of $\mathrm{NO}_{\mathrm{x}}$ emissions in the US EPA National Emission Inventory (Travis et al., 2016). However, midday ozonesondes also show a large vertical gradient of decreasing ozone below $1 \mathrm{~km}$ altitude that is at odds 
Atmos. Chem. Phys. Discuss., https://doi.org/10.5194/acp-2017-596

Manuscript under review for journal Atmos. Chem. Phys.

Discussion started: 1 August 2017

(c) Author(s) 2017. CC BY 4.0 License.

(c) (i)

with the strong mixing expected from models. Here we investigated the cause of this discrepancy through the combined analysis of August-September 2013 ozone observations from aircraft (SEAC ${ }^{4} R S$ ), surface (CASTNET), and ozonesondes (SEACIONS).

Statistical comparison of the GEOS-Chem model to aircraft observations of ozone below $1 \mathrm{~km}$ shows no significant bias (50 \pm 10

5 ppb observed, $52 \pm 10 \mathrm{ppb}$ model), but the maximum daily 8-h average (MDA8) surface ozone at CASTNET sites is overestimated by $8 \pm 9 \mathrm{ppb}$ ( $40 \pm 9 \mathrm{ppb}$ observed, $48 \pm 9 \mathrm{ppb}$ model). The lowest model level is centered at $60 \mathrm{~m}$ above ground while the observations are at $10 \mathrm{~m}$; thus a subgrid correction must be applied using the model aerodynamic resistance to dry deposition. This correction, which is generally ignored in models, averages $3 \mathrm{ppb}$ in our case; it is relatively large because the MDA8 8-hour window can include convectively stable conditions. The resulting model ozone at $10 \mathrm{~m}$ is $45 \pm 8 \mathrm{ppb}$, still significantly higher than

10 observed. August-September 2013 was cooler and wetter than average but the effect on ozone was small, averaging 2 ppb at CASTNET sites. The low tail of observed MDA8 ozone $(<25 \mathrm{ppb})$ was largely associated with rainy conditions.

The GEOS-FP meteorological data driving GEOS-Chem are biased toward clear-sky, and this bias would be expected to contribute to the overestimate of ozone. However, we find that the model MDA8 ozone is only 4 ppb lower under low-cloud and rainy

15 conditions than in clear sky, whereas in the observations that difference is $7 \mathrm{ppb}$ under low-cloud conditions and $11 \mathrm{ppb}$ under rainy conditions. Midday ozonesonde data from Huntsville, Alabama show a $6 \mathrm{ppb}$ decrease from $1 \mathrm{~km}$ to the surface ( $4 \mathrm{ppb}$ under clear-sky, 7 ppb under low cloud), whereas the model shows only a 1 ppb decrease. Thus the model has excessive top-down mixing of ozone; this is seen using both the Holtslag and Boville (1993) PBL scheme in the off-line GEOS-Chem and the Lock et al. (2000) scheme in the GEOS-5 GCM. By contrast, potential temperature shows similar strong vertical mixing in the observations

20 and the model. Bottom-up mixing (as for heat) is known to be faster than top-down mixing (as for ozone) because of buoyant plumes but the two above schemes do not include this asymmetry. The ACM2 scheme (Pleim, 2007a, b) includes this asymmetry, but previous evaluations suggest that this scheme still has excessive downward mixing of ozone. We find in a sensitivity simulation that decreasing top-down eddy diffusion following Wyngaard and Brost (1984) and suppressing top-down non-local vertical transport allows GEOS-Chem to successfully simulate the observed ozone gradient in the mixed layer. More work is needed to

25 describe the top-down mixing of ozone for air quality applications.

\section{Data availability}

Cloud data from the Automated Surface Observing System (ASOS) can be downloaded here: http://mesonet.agron.iastate.edu/request/download.phtml. PRISM temperature and precipitation data can be downloaded here: http://www.prism.oregonstate.edu/historical/. The SEACIONS ozonesonde data can be accessed here:

30 https://tropo.gsfc.nasa.gov/seacions. The CERES cloud fraction and cloud optical depth observations are available at http://doi.org/10.5067/Aqua/CERES/ISCCP-D2LIKE-MERG00 L3.003. The SEAC ${ }^{4} R S$ aircraft data can be found here: https://www-air.larc.nasa.gov/missions/seac4rs/DC8-Extract.html. CASTNET data are available at: https://www.epa.gov/castnet.

\section{Competing Interests}

The authors declare that they have no conflict of interest.

Acknowledgements 
Atmos. Chem. Phys. Discuss., https://doi.org/10.5194/acp-2017-596

Manuscript under review for journal Atmos. Chem. Phys.

We thank Randal Koster (NASA), Dan Goldberg (ANL), and Taylor Jones, Eloise Marais, Rachel Silvern, and Lu Shen (Harvard) for helpful discussions. This work was supported by the NASA Earth Science Division. AMT acknowledges SEACIONS support from the Tropospheric Chemistry Program to NASA/Goddard, NOAA/ESRL/GMD and originally to Penn State University (Grant NNX12AF05G).

\section{$5 \quad 10$ References}

Altimir, N., Kolari, P., Tuovinen, J.-P., Vesala, T., Back, J., Suni, T., Kulmala, M., and Hari, P.: Foliage surface ozone deposition: a role for surface moisture?, Biogeosciences, 3, 209-228, doi: http://www.biogeosciences.net/3/209/2006/, 2006.

Anderson, D. C., Loughner, C. P., Diskin, G., Weinheimer, A., Canty, T., P., Salawitch, R. J., Worden, H. M., Fried, A., Mikoviny, T., Wisthaler, A., and Dickerson, R., R.: Measured and modeled CO and $\mathrm{NO}_{\mathrm{y}}$ in DISCOVER-AQ: An evaluation of emissions and chemistry over the eastern US, Atmos. Environ., 96, 78-87, doi: 10.1016/j.atmosenv.2014.07.004, 2014.

Brioude, J., Angevine, W. M., Ahmadov, R., Kim, S. W., Evan, S., McKeen, S. A., Hsie, E. Y., Frost, G. J., Neuman, J. A., Pollack, I. B., Peischl, J., Ryerson, T. B., Holloway, J., Brown, S. S., Nowak, J. B., Roberts, J. M., Wofsy, S. C., Santoni, G. W., Oda, T., and Trainer, M.: Top-down estimate of surface flux in the Los Angeles Basin using a mesoscale inverse modeling technique: assessing anthropogenic emissions of $\mathrm{CO}, \mathrm{NO}_{\mathrm{x}}$ and $\mathrm{CO}_{2}$ and their impacts, Atmos. Chem. Phys., 13, 36613677, doi: 10.5194/acp-13-3661-2013, 2013.

Brown-Steiner, B., Hess, P. G., and Lin, M. Y.: On the capabilities and limitations of GCCM simulations of summertime regional air quality: A diagnostic analysis of ozone and temperature simulations in the US using CESM CAM-Chem, Atmos. Environ., 101, doi: 134-148, 10.1016/j.atmosenv.2014.11.001, 2015.

Canty, T. P., Hembeck, L., Vinciguerra, T. P., Anderson, D. C., Goldberg, D. L., Carpenter, S. F., Allen, D. J., Loughner, C. P., Salawitch, R. J., and Dickerson, R. R.: Ozone and $\mathrm{NO}_{\mathrm{x}}$ chemistry in the eastern US: evaluation of CMAQ/CB05 with satellite (OMI) data, Atmos. Chem. Phys. Discussions, 15, 4427-4461, doi: 10.5194/acpd-15-4427-2015, 2015.

Carlton, A. M., de Gouw, J., Jimenez, J. L., Ambrose, J. L., Brown, S., Baker, K. R., Brock, C. A., Cohen, R. C., Edgerton, S., Farkas, C., Farmer, D., Goldstein, A. H., Gratz, L., Guenther, A., Hunt, S., Jaeglé, L., Jaffe, D. A., Mak, J., McClure, C., Nenes, A., Nguyen, T. K. V., Pierce, J. R., Selin, N., Shah, V., Shaw, S., Shepson, P. B., Song, S., Stutz, J., Surratt, J., Turpin, B. J., Warneke, C., Washenfelder, R. A., Wennberg, P. O., and Zhou, X. Atmosphere Studies (SAS): Coordinated Investigation and Discovery to Answer Critical Questions About Fundamental Atmospheric Processes. Bull. Am. Met. Soc, submitted, 2016.

Chai, T., Kim, H. C., Lee, P., Tong, D., Pan, L., Tang, Y., Huang, J., McQueen, J., Tsidulko, M., and Stajner, I.: Evaluation of the United States National Air Quality Forecast Capability experimental real-time predictions in 2010 using Air Quality System ozone and NO2 measurements, Geosci. Model Dev., 6, 1831-1850, doi: 10.5194/gmd-6-1831-2013, 2013.

Chepfer, H., Bony, S., Winker, D., Chiriaco, M., Dufresne, J. L., and Sèze, G.: Use of CALIPSO lidar observations to evaluate the cloudiness simulated by a climate model, Geophys. Res. Lett., 35, doi: 10.1029/2008g1034207, 2008.

Deardorff, J. W.: The Counter-Gradient Heat Flux in the Lower Atmosphere and in the Laboratory, J. Atmos. Sci., 23, 503-506, 1966.

35 National Emissions Inventory (NEI) Air Pollutant Emission Trends Data: http://www.epa.gov/ttn/chief/trends/index.html, 2015.

Finkelstein, P. L., Ellestad, T. G., Clarke, J. F., Meyers, T. P., Schwede, D. B., Hebert, E. O., and Neal, J. A.: Ozone and sulfur dioxide dry deposition to forests: Observations and model evaluation, J. Geophys. Res.-Atmos., 105, 15365-15377, doi 10.1029/2000jd900185, 2000. 
Atmos. Chem. Phys. Discuss., https://doi.org/10.5194/acp-2017-596

Manuscript under review for journal Atmos. Chem. Phys.

Discussion started: 1 August 2017

(c) Author(s) 2017. CC BY 4.0 License.

Fiore, A. M., Jacob, D. J., Bey, I., Yantosca, R. M., Field, B. D., and Fusco, A. C.: Background ozone over the United States in summer: Origin, trend, and contribution to pollution episodes, J. Geophys. Res.,, 107, doi: 10.1029/2001JD000982, 2002.

Fiore, A. M., Jacob, D. J., Liu, H., Yantosca, R. M., Fairlie, T. D., and Li, Q.: Variability in surface ozone background over the United States: Implications for air quality policy, J. Geophys. Res.-Atmos., 108, doi: 10.1029/2003jd003855, 2003.

5 Fiore, A. M., Horowitz, L. W., Purves, D. W., Levy, H., Evans, M. J., Wang, Y., Li, Q., and Yantosca, R.: Evaluating the contribution of changes in isoprene emissions to surface ozone trends over the eastern United States, J. Geophys. Res., 110, doi: 10.1029/2004jd005485, 2005.

Fiore, A. M., Dentener, F. J., Wild, O., Cuvelier, C., Schultz, M. G., Hess, P., Textor, C., Schulz, M., Doherty, R. M., Horowitz, L. W., MacKenzie, I. A., Sanderson, M. G., Shindell, D. T., Stevenson, D. S., Szopa, S., Van Dingenen, R., Zeng, G., Atherton, C., Bergmann, D., Bey, I., Carmichael, G., Collins, W. J., Duncan, B. N., Faluvegi, G., Folberth, G., Gauss, M., Gong, S., Hauglustaine, D., Holloway, T., Isaksen, I. S. A., Jacob, D. J., Jonson, J. E., Kaminski, J. W., Keating, T. J., Lupu, A., Marmer, E., Montanaro, V., Park, R. J., Pitari, G., Pringle, K. J., Pyle, J. A., Schroeder, S., Vivanco, M. G., Wind, P., Wojcik, G., Wu, S., and Zuber, A.: Multimodel estimates of intercontinental source-receptor relationships for ozone pollution, J. Geophys. Res., 114, doi: 10.1029/2008jd010816, 2009.

15 Fisher, J. A., Jacob, D. J., Travis, K. R., Kim, P. S., Marais, E. A., Chan Miller, C., Yu, K., Zhu, L., Yantosca, R. M., Sulprizio, M. P., Mao, J., Wennberg, P. O., Crounse, J. D., Teng, A. P., Nguyen, T. B., St. Clair, J. M., Cohen, R. C., Romer, P., Nault, B. A., Wooldridge, P. J., Jimenez, J. L., Campuzano-Jost, P., Day, D. A., Hu, W., Shepson, P. B., Xiong, F., Blake, D. R., Goldstein, A. H., Misztal, P. K., Hanisco, T. F., Wolfe, G. M., Ryerson, T. B., Wisthaler, A., and Mikoviny, T.: Organic nitrate chemistry and its implications for nitrogen budgets in an isoprene- and monoterpene-rich atmosphere: constraints from aircraft (SEAC ${ }^{4} \mathrm{RS}$ ) and ground-based (SOAS) observations in the Southeast US, Atmos. Chem. Phys., 16, 5969-5991, doi: 10.5194/acp-16-5969-2016, 2016.

Fujita, E. M., Campbell, D. E., Zielinska, B., Chow, J. C., Lindhjem, C. E., DenBleyker, A., Bishop, G. A., Schuchmann, B. G., Stedman, D. H., and Lawson, D. R.: Comparison of the MOVES2010a, MOBILE6.2, and EMFAC2007 mobile source emission models with on-road traffic tunnel and remote sensing measurements, J. Air Waste Manage., 62, 1134-1149, doi:10.1080/10962247.2012.699016, 2012.

Goldberg, D. L.: Lifetime and Distribution of Ozone and Related Pollutants in the Eastern United States, Doctor of Philosophy, Department of Atmospheric and Oceanic Science, University of Maryland, College Park, 2015.

Holtslag, A. A. M., and Moeng, C. H.: Eddy diffusivity and countergradient transport in the convective atmospheric boundary layer, J. Atmos. Sci., 48, 1690-1698, 1991.

30 Holtslag, A. A. M., and Boville, B. A.: Local Versus Nonlocal Boundary-Layer Diffusion in a Global Climate Model, J. Climate, 6, 1825-1842, doi: 10.1175/1520-0442(1993)006<1825:Lvnbld>2.0.Co;2, 1993.

Horowitz, L. W., Fiore, A. M., Milly, G. P., Cohen, R. C., Perring, A., Wooldridge, P. J., Hess, P. G., Emmons, L. K., and Lamarque, J. F.: Observational constraints on the chemistry of isoprene nitrates over the eastern United States, J. Geophys. Res.-Atmos., 112, doi: 10.1029/2006jd007747, 2007.

35 Kay, J. E., Hillman, B. R., Klein, S. A., Zhang, Y., Medeiros, B., Pincus, R., Gettelman, A., Eaton, B., Boyle, J., Marchand, R., and Ackerman, T. P.: Exposing Global Cloud Biases in the Community Atmosphere Model (CAM) Using Satellite Observations and Their Corresponding Instrument Simulators, J. Climate, 25, 5190-5207, doi: 10.1175/jcli-d-11-00469.1, 2012.

Kim, H. C., Lee, P., Ngan, F., Tang, Y., Yoo, H. L., and Pan, L.: Evaluation of modeled surface ozone biases as a function of cloud cover fraction, Geosci. Model Dev., 8, 2959-2965, doi: 10.5194/gmd-8-2959-2015, $2015 \mathrm{a}$. 
Atmos. Chem. Phys. Discuss., https://doi.org/10.5194/acp-2017-596

Atmospheric

Chemistry

Manuscript under review for journal Atmos. Chem. Phys.

Discussion started: 1 August 2017

(c) Author(s) 2017. CC BY 4.0 License.

Kim, P. S., Jacob, D. J., Fisher, J. A., Travis, K., Yu, K., Zhu, L., Yantosca, R. M., Sulprizio, M. P., Jimenez, J. L., CampuzanoJost, P., Froyd, K. D., Liao, J., Hair, J. W., Fenn, M. A., Butler, C. F., Wagner, N. L., Gordon, T. D., Welti, A., Wennberg, P. O., Crounse, J. D., St. Clair, J. M., Teng, A. P., Millet, D. B., Schwarz, J. P., Markovic, M. Z., and Perring, A. E.: Sources, seasonality, and trends of southeast US aerosol: an integrated analysis of surface, aircraft, and satellite observations with the GEOS-Chem chemical transport model, Atmos. Chem. Phys., 15, 10411-10433, doi: 10.5194/acp15-10411-2015, 2015b.

Lin, J., Youn, D., Liang, X., and Wuebbles, D.: Global model simulation of summertime U.S. ozone diurnal cycle and its sensitivity to PBL mixing, spatial resolution, and emissions, Atmos. Environ., 42, 8470-8483, doi: 10.1016/j.atmosenv.2008.08.012, 2008.

10 Lin, J.-T., and McElroy, M. B.: Impacts of boundary layer mixing on pollutant vertical profiles in the lower troposphere: Implications to satellite remote sensing, Atmos. Environ., 44, 1726-1739, doi: 10.1016/j.atmosenv.2010.02.009, 2010.

Lin, M., Horowitz, L. W., Payton, R., Fiore, A. M., and Tonnesen, G.: US surface ozone trends and extremes from 1980 to 2014 : quantifying the roles of rising Asian emissions, domestic controls, wildfires, and climate, Atmos. Chem. Phys., 17, 29432970, doi: 10.5194/acp-17-2943-2017, 2017.

15 Liu, H., Crawford, J. H., Pierce, R. B., Norris, P., Platnick, S. E., Chen, G., Logan, J. A., Yantosca, R. M., Evans, M. J., Kittaka, C., Feng, Y., and Tie, X.: Radiative effect of clouds on tropospheric chemistry in a global three-dimensional chemical transport model, J. Geophys. Res., 111, doi: 10.1029/2005jd006403, 2006.

Lock, A. P., Brown, A. R., Bush, M. R., Martin, G. M., and Smith, R. N. B.: A New Boundary Layer Mixing Scheme. Part I: Scheme Description and Single-Column Model Tests, Monthly Weather Review, 128, 3187-3199, 2000.

20 Long, M. S., Yantosca, R., Nielsen, J. E., Keller, C. A., da Silva, A., Sulprizio, M. P., Pawson, S., and Jacob, D. J.: Development of a grid-independent GEOS-Chem chemical transport model (v9-02) as an atmospheric chemistry module for Earth system models, Geosci. Model Dev., 8, 595-602, 2015.

Marais, E. A., Jacob, D. J., Jimenez, J. L., Campuzano-Jost, P., Day, D. A., Hu, W., Krechmer, J., Zhu, L., Kim, P. S., Miller, C. C., Fisher, J. A., Travis, K., Yu, K., Hanisco, T. F., Wolfe, G. M., Arkinson, H. L., Pye, H. O. T., Froyd, K. D., Liao, J., and McNeill, V. F.: Aqueous-phase mechanism for secondary organic aerosol formation from isoprene: application to the southeast United States and co-benefit of $\mathrm{SO}_{2}$ emission controls, Atmos. Chem. Phys., 16, 1603-1618, doi: 10.5194/acp16-1603-2016, 2016.

McDonald-Buller, E. C., Allen, D. T., Brown, N., Jacob, D. J., Jaffe, D., Kolb, C. E., Lefohn, A. S., Oltmans, S., Parrish, D. D., Yarwood, G., and Zhang, L.: Establishing policy relevant background (PRB) ozone concentrations in the United States, Env. Sci. Tech., 45, 9484-9497, doi: 10.1021/es2022818, 2011.

McGrath-Spangler, E. L., and Molod, A.: Comparison of GEOS-5 AGCM planetary boundary layer depths computed with various definitions, Atmos. Chem. Phys., 14, 6717-6727, doi: 10.5194/acp-14-6717-2014, 2014.

Miller, C. C., Jacob, D. J., Marais, E. A., Yu, K., Travis, K. R., Kim, P. S., Fisher, J. A., Zhu, L., Wolfe, G. M., Keutsch, F. N., Kaiser, J., Min, K.-E., Brown, S. S., Washenfelder, R. A., González Abad, G., and Chance, K.: Glyoxal yield from isoprene oxidation and relation to formaldehyde: chemical mechanism, constraints from SENEX aircraft observations, and interpretation of OMI satellite data, Atmospheric Chemistry and Physics Discussions, 1-25, doi: 10.5194/acp-2016$1042,2017$.

Minnis, P., Smith Jr, W. L., DP, G., and JK, A.: Cloud properties derived from GOES-7 for Spring 1994 ARM intensive observing period using Version 1.0.0 of ARM Satellite Data Analysis Program, 1995. 
Atmos. Chem. Phys. Discuss., https://doi.org/10.5194/acp-2017-596

Manuscript under review for journal Atmos. Chem. Phys.

Discussion started: 1 August 2017

(c) Author(s) 2017. CC BY 4.0 License.
Atmospheric

Chemistry

and Physics

Discussions

Minnis, P., Sun-Mack, S., Young, D. F., Heck, P. W., Garber, D. P., Chen, Y., Spangenberg, D. A., Arduini, R. F., Trepte, Q. Z., Smith, W. L., Ayers, J. K., Gibson, S. C., Miller, W. F., Hong, G., Chakrapani, V., Takano, Y., Liou, K.-N., Xie, Y., and Yang, P.: CERES Edition-2 Cloud Property Retrievals Using TRMM VIRS and Terra and Aqua MODIS Data\&\#x2014;Part I: Algorithms, IEEE Transactions on Geoscience and Remote Sensing, 49, 4374-4400, doi: 10.1109/tgrs.2011.2144601, 2011.

Molod, A., Takacs, L., Suarez, M., Bacmeister, J., Song, I., and Eichmann, A.: The GEOS-5 Atmospheric General Circulation Model: Mean Climate and Development from MERRA to Fortuna, National Aeronautics and Space Administration, Goddard Space Flight Center, 2012.

Molod, A., Takacs, L., Suarez, M., and Bacmeister, J.: Development of the GEOS-5 atmospheric general circulation model: evolution from MERRA to MERRA2, Geosci. Model Dev., 8, 1339-1356, doi: 10.5194/gmd-8-1339-2015, 2015.

Mueller, S. F., Bailey, E. M., Cook, T. M., and Mao, Q.: Treatment of clouds and the associated response of atmospheric sulfur in the Community Multiscale Air Quality (CMAQ) modeling system, Atmos. Environ., 40, 6804-6820, doi: 10.1016/j.atmosenv.2006.05.069, 2006.

Nam, C., Bony, S., Dufresne, J. L., and Chepfer, H.: The 'too few, too bright' tropical low-cloud problem in CMIP5 models, Geophys. Res. Lett., 39, n/a-n/a, doi: 10.1029/2012gl053421, 2012.

Naud, C. M., Del Genio, A. D., Bauer, M., and Kovari, W.: Cloud Vertical Distribution across Warm and Cold Fronts inCloudSatCALIPSO Data and a General Circulation Model, J Climate, 23, 3397-3415, doi: 10.1175/2010jcli3282.1, 2010.

Newchurch, M. J., Ayoub, M. A., Oltmans, S., Jobson, B., and Schmidlin, F. J.: Vertical distribution of ozone at four sites in the United States, J. Geophys. Res., 108, doi: 10.1029/2002jd002059, 2003.

20 Pleim, J. E., and Chang, J. S.: A Non-Local Closure Model for Vertical Mixing in the Convective Boundary Layer, Atmos. Environ., 26A, 965-981, 1992.

Pleim, J. E.: A Combined Local and Nonlocal Closure Model for the Atmospheric Boundary Layer. Part II: Application and Evaluation in a Mesoscale Meteorological Model, J. App. Met. Clim., 46, 1396-1409, doi: 10.1175/jam2534.1, 2007a.

Pleim, J. E.: A Combined Local and Nonlocal Closure Model for the Atmospheric Boundary Layer. Part I: Model Description and Testing, J. App. Met. Clim., 46, 1383-1395, doi: 10.1175/jam2539.1, $2007 \mathrm{~b}$.

Potier, E., Loubet, B., Durand, B., Flura, D., Bourdat-Deschamps, M., Ciuraru, R., and Ogee, J.: Chemical reaction rates of ozone in water infusions of wheat, beech, oak and pine leaves of different ages, Atmos. Environ., 151, 176-187, doi: 10.1016/j.atmosenv.2016.11.069, 2017.

Pour-Biazar, A., McNider, R. T., Roselle, S. J., Suggs, R., Jedlovec, G., Byun, D. W., Kim, S., Lin, C. J., Ho, T. C., Haines, S., Dornblaser, B., and Cameron, R.: Correcting photolysis rates on the basis of satellite observed clouds, J. Geophys. Res., 112, doi: 10.1029/2006jd007422, 2007.

Reidmiller, D. R., Fiore, A. M., Jaffe, D. A., Bergmann, D., Cuvelier, C., Dentener, F. J., Duncan, B. N., Folberth, G., Gauss, M., Gong, S., Hess, P., Jonson, J. E., Keating, T., Lupu, A., Marmer, E., Park, R., Schultz, M. G., Shindell, D. T., Szopa, S., Vivanco, M. G., Wild, O., and Zuber, A.: The influence of foreign vs. North American emissions on surface ozone in the US, Atmos. Chem. Phys., 9, 5027-5042, 2009.

Ryu, Y.-H., Hodzic, A., Descombes, G., Hall, S., Minnis, P., Spangenberg, D., Ullmann, K., and Madronich, S.: Improved modeling of cloudy-sky actinic flux using satellite cloud retrievals, Geophys. Res. Lett., 44, 1592-1600, doi: 10.1002/2016gl071892, 2017. 
Atmos. Chem. Phys. Discuss., https://doi.org/10.5194/acp-2017-596

Manuscript under review for journal Atmos. Chem. Phys.

Discussion started: 1 August 2017

(c) Author(s) 2017. CC BY 4.0 License.
Atmospheric

Chemistry

and Physics

Discussions

Squire, O. J., Archibald, A. T., Griffiths, P. T., Jenkin, M. E., Smith, D., and Pyle, J. A.: Influence of isoprene chemical mechanism on modelled changes in tropospheric ozone due to climate and land use over the $21^{\text {st }}$ century, Atmos. Chem. Phys., 15, 5123-5143, doi: 10.5194/acp-15-5123-2015, 2015.

Tang, W., Cohan, D. S., Morris, G. A., Byun, D. W., and Luke, W. T.: Influence of vertical mixing uncertainties on ozone simulation in CMAQ, Atmos. Environ., 45, 2898-2909, doi: 10.1016/j.atmosenv.2011.01.057, 2011.

Tang, W., Cohan, D. S., Pour-Biazar, A., Lamsal, L. N., White, A. T., Xiao, X., Zhou, W., Henderson, B. H., and Lash, B. F.: Influence of satellite-derived photolysis rates and $\mathrm{NO}_{\mathrm{x}}$ emissions on Texas ozone modeling, Atmos. Chem. Phys., 15, 1601-1619, doi: 10.5194/acp-15-1601-2015, 2015.

Toon, O. B., Maring, H., Dibb, J., Ferrare, R., Jacob, D. J., Jensen, E. J., Luo, Z. J., Mace, G. G., Pan, L. L., Pfister, L., Rosenlof,

K. H., Redemann, J., Reid, J. S., Singh, H. B., Thompson, A. M., Yokelson, R. J., Minnis, P., Chen, G., Jucks, K. W., and Pszenny, A.: Planning, implementation, and scientific goals of the Studies of Emissions and Atmospheric Composition, Clouds, and Climate Coupling by Regional Surveys (SEAC ${ }^{4}$ RS) field mission, J. Geophys. Res.-Atmos., 121, 4967-5009, doi: 10.1002/2015JD024297, 2016.

Travis, K. R., Jacob, D. J., Fisher, J. A., Kim, P. S., Marais, E. A., Zhu, L., Yu, K., Miller, C. C., Yantosca, R. M., Sulprizio, M. P., Thompson, A. M., Wennberg, P. O., Crounse, J. D., St. Clair, J. M., Cohen, R. C., Laughner, J. L., Dibb, J. E., Hall, S. R., Ullmann, K., Wolfe, G. M., Pollack, I. B., Peischl, J., Neuman, J. A., and Zhou, X.: Why do Models Overestimate Surface Ozone in the Southeast United States?, Atmos. Chem. Phys., 16, 3561-13577, doi: 10.5194/acp-16-13561-2016, 2016.

Voulgarakis, A., Wild, O., Savage, N. H., Carver, G. D., and Pyle, J. A.: Clouds, photolysis and regional tropospheric ozone budgets, Atmos. Chem. Phys., 9, 8235-8246, 2009.

Wang, Y., Jacob, D. J., and Logan, J. A.: Global simulation of tropospheric O3-NOx-hydrocarbon chemistry 1. Model formulation, J. Geophys. Res., 3/D9, 10,713-710,726, 1998.

Wesely, M. L.: Parameterization of Surface Resistances to Gaseous Dry Deposition in Regional-Scale Numerical-Models, Atmos. Environ., 23, 1293-1304, doi: 10.1016/0004-6981(89)90153-4, 1989.

Wolfe, G. M., Hanisco, T. F., Arkinson, H. L., Bui, T. P., Crounse, J. D., Dean-Day, J., Goldstein, A., Guenther, A., Hall, S. R., Huey, G., Jacob, D. J., Karl, T., Kim, P. S., Liu, X., Marvin, M. R., Mikoviny, T., Misztal, P. K., Nguyen, T. B., Peischl, J., Pollack, I., Ryerson, T., St. Clair, J. M., Teng, A., Travis, K. R., Ullmann, k., Wennberg, P. O., and Wisthaler, A.: Quantifying sources and sinks of reactive gases in the lower atmosphere using airborne flux observations, Geophys. Res. Lett., 42, 8231-8240, 2015.

Wyngaard, J. C., and Brost, R. A.: Top-Down and Bottom-Up Diffusion of a Scalar in the Convective Boundary Layer, J. Atmos. Sci., 41, 102-112, 1984.

Xie, B., and Fung, J. C. H.: A comparison of momentum mixing models for the planetary boundary layer, J. Geophys. Res.- Atmos., 119, 2079-2091, doi: 10.1002/2013jd020273, 2014.

Yu, K., Jacob, D. J., Fisher, J. A., Kim, P. S., Marais, E. A., Miller, C. C., Travis, K. R., Zhu, L., Yantosca, R. M., Sulprizio, M. P., Cohen, R. C., Dibb, J. E., Fried, A., Mikoviny, T., Ryerson, T. B., Wennberg, P. O., and Wisthaler, A.: Sensitivity to grid resolution in the ability of a chemical transport model to simulate observed oxidant chemistry under high-isoprene conditions, Atmos. Chem. Phys., 16, 4369-4378, doi: 10.5194/acp-16-4369-2016, 2016.

Yu, S., Mathur, R., Pleim, J., Pouliot, G., Wong, D., Eder, B., Schere, K., Gilliam, R., and Rao, S. T.: Comparative evaluation of the impact of WRF-NMM and WRF-ARW meteorology on CMAQ simulations for O3 and related species during the 2006 TexAQS/GoMACCS campaign, Atmos. Poll. Res., doi: 10.5094/apr.2012.015, 2012. 
Atmos. Chem. Phys. Discuss., https://doi.org/10.5194/acp-2017-596

Manuscript under review for journal Atmos. Chem. Phys.

Discussion started: 1 August 2017

(C) Author(s) 2017. CC BY 4.0 License.
Atmospheric 을

Chemistry

and Physics

Discussions

(c) (i)

Zhang, L., Jacob, D. J., Knipping, E. M., Kumar, N., Munger, J. W., Carouge, C. C., van Donkelaar, A., Wang, Y. X., and Chen, D.: Nitrogen deposition to the United States: distribution, sources, and processes, Atmos. Chem. Phys., 12, 4539-4554, doi: 10.5194/acp-12-4539-2012, 2012.

Zhang, M. H.: Comparing clouds and their seasonal variations in 10 atmospheric general circulation models with satellite measurements, J. Geophys. Res., 110, doi: 10.1029/2004jd005021, 2005.

Zhu, L., Jacob, D. J., Mickley, L. J., Kim, P. S., Fisher, J. A., Travis, K. R., Yu, K., Yantosca, R. M., Sulprizio, M. P., Fried, A., Hanisco, T., Wolfe, G., Abad, G. G., Chance, K., De Smedt, I., and Yang, K.: Observing atmospheric formaldehyde (HCHO) from space: validation and intercomparison of six retrievals from four satellites (OMI, GOME2A, GOME2B, OMPS) with SEAC ${ }^{4}$ RS aircraft observations over the Southeast US, Atmos. Chem. Phys., 16, 13477-13490, doi:

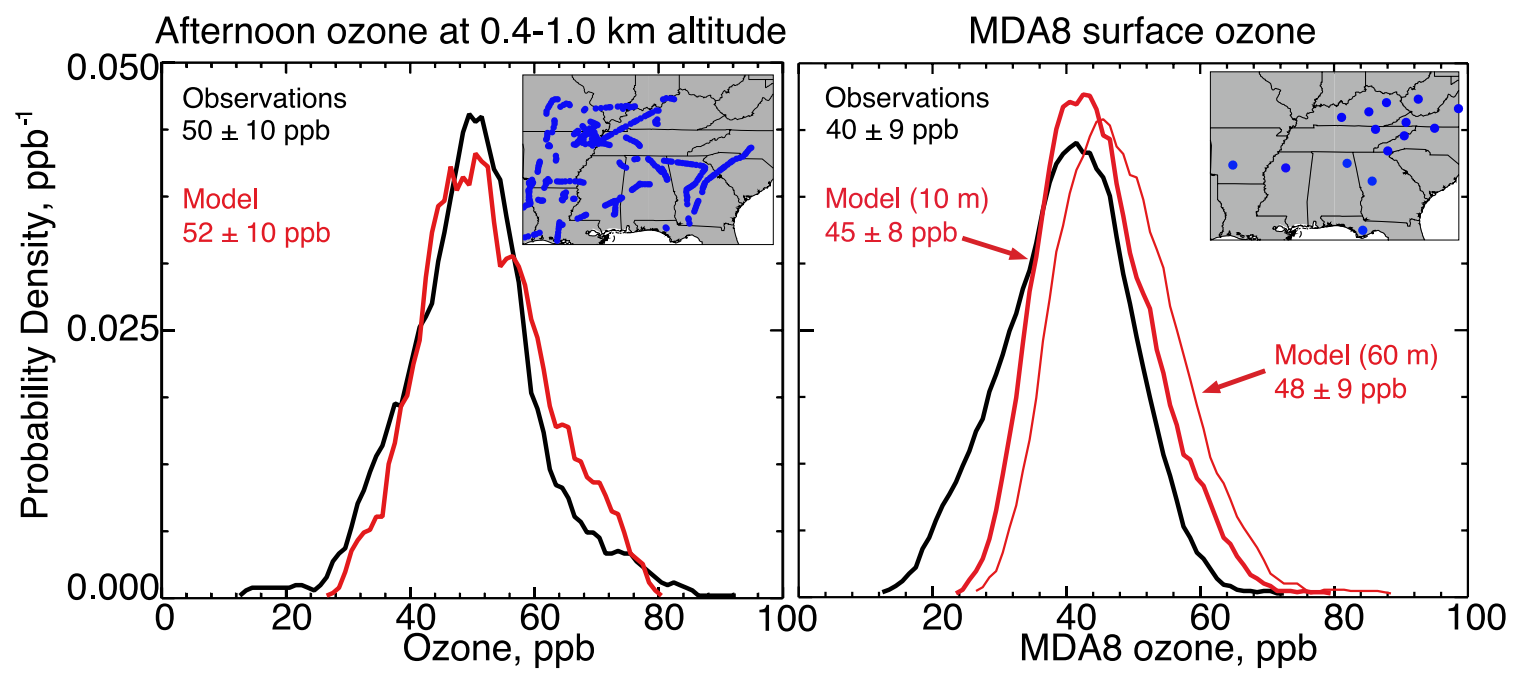

Figure 1 - Probability density functions (pdfs) of ozone concentrations in the Southeast US (94.5-80 W, 29.5-38 N, maps inset with sampling locations indicated) in August-September 2013. Mean and standard deviation are given for each pdf. The left panel shows afternoon (12-18 local time) mixed layer values measured by the SEAC ${ }^{4} \mathrm{RS}$ DC8 aircraft at $0.4-1.0 \mathrm{~km}$ altitude $(n=370)$. The right panel shows maximum 8 -hour daily average (MDA8) near-surface values (about $10 \mathrm{~m}$ above the local surface) measured at the CASTNET network of 15 rural sites. Also shown are the corresponding GEOS-Chem model pdfs sampled at the locations and times of the observations. The thin red line in the right panel is the model pdf for the lowest model level (centered at $60 \mathrm{~m}$ above ground). The thick red line is the implied model value at $10 \mathrm{~m}$ (see text). 
Atmos. Chem. Phys. Discuss., https://doi.org/10.5194/acp-2017-596

Manuscript under review for journal Atmos. Chem. Phys.

Discussion started: 1 August 2017

(c) Author(s) 2017. CC BY 4.0 License.
Atmospheric 을

Chemistry

and Physics

Discussions
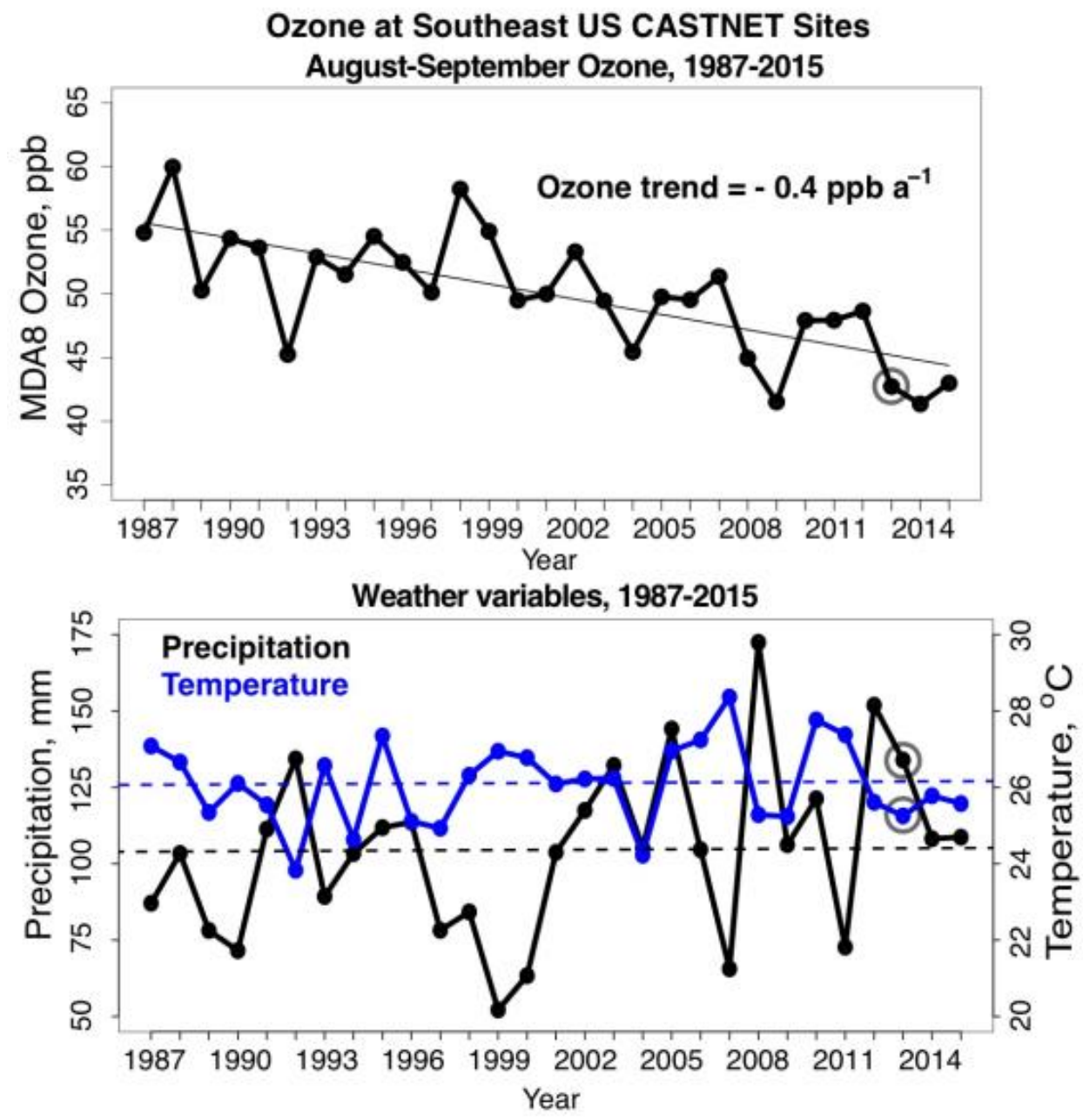

Figure 2 - Ozone and weather variables averaged over the 15 Southeast US CASTNET sites of Figure 1, 1987-2015. The top panel shows the 1987-2015 trend in August-September MDA8 ozone, with linear regression indicated. The bottom panel shows 1987-2015 August-September average daily temperature (blue) and average of August and September total precipitation (black) from the PRISM Climate Group datasets (http://www.prism.oregonstate.edu). Dashed lines indicate the 1987-2015 mean values. Grey circles highlight 2013. 

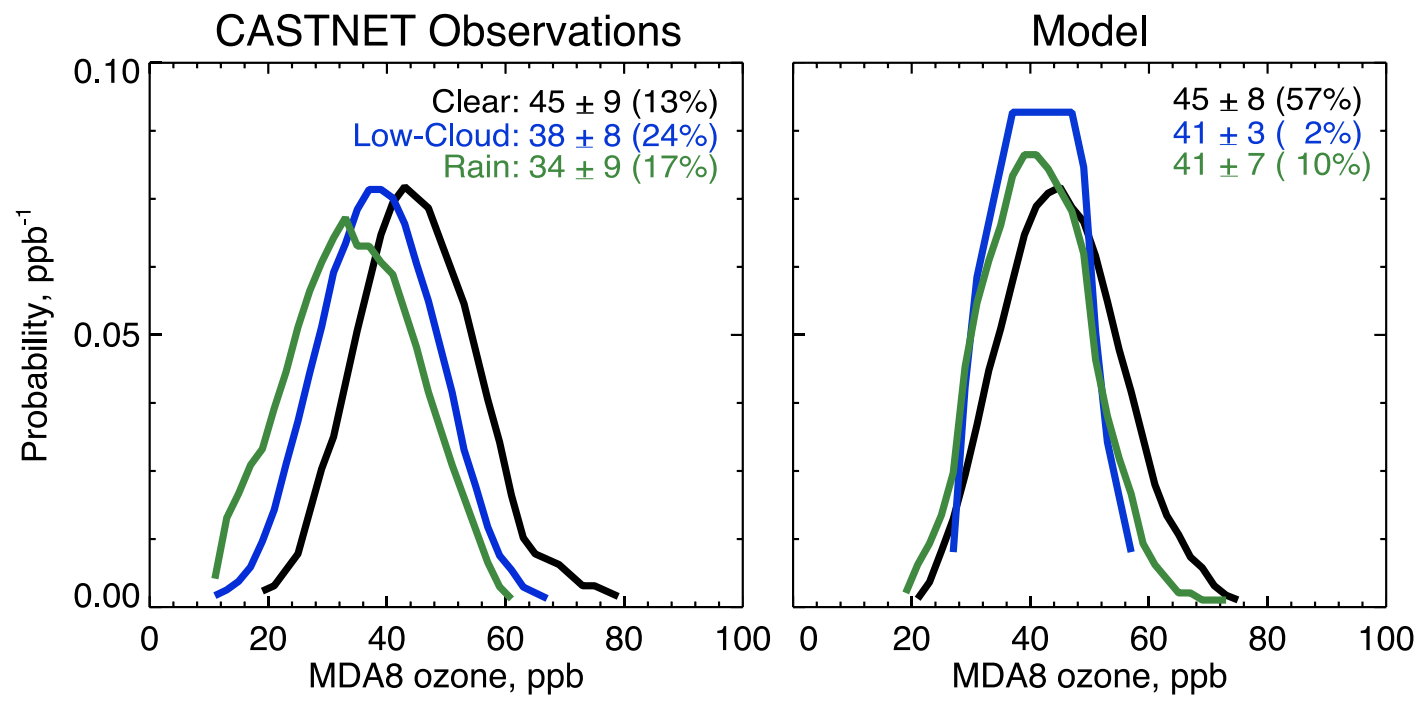

Figure 3 - Maximum daily 8-h average (MDA8) ozone probability density functions (pdfs) at CASTNET sites in the Southeast US in AugustSeptember 2013. The pdfs are segregated between clear-sky, low cloud, and rainy conditions as described in Section 4 . The model pdfs include the correction for $10 \mathrm{~m}$ ozone described in Section 3. For each sky condition, the mean ozone and its standard deviation are given inset with the 5 frequency of that sky condition in parentheses. The frequencies do not add up to $100 \%$ because partial low-cloud cover (0.5-3 oktas) is not included.

\section{Daytime low-cloud fraction, Aug-Sep 2013}

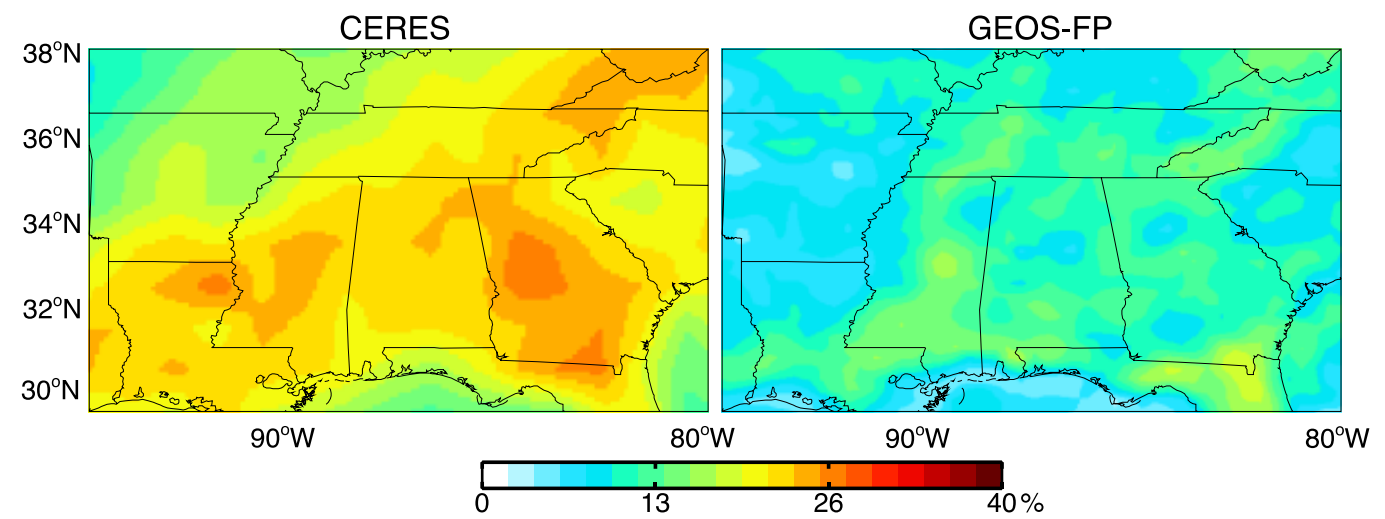

Figure 4 - Average daytime low-cloud fraction (below $680 \mathrm{hPa}, 9-17$ local time) in August-September 2013. The left panel shows satellite data from the CERES ISCCP-D2like product (CERES Science Team, Hampton, VA, USA: NASA Atmospheric Science Data Center, accessed May, 2016, at http://doi.org/10.5067/Aqua/CERES/ISCCP-D2LIKE-MERG00_L3.003A). This merged product combines 3-hourly, daytime cloud properties from Terra and Aqua on the Moderate Resolution Imaging Spectroradiometer (MODIS) and geostationary meteorological satellites mapped on a $1^{\circ} \times 1^{\circ}$ grid (Minnis et al., 2011). The right panel shows data from GEOS-FP where cloud fraction and in-cloud optical depth are provided for each model level using the maximum random overlap scheme (MRAN) to derive total cloudiness below $680 \mathrm{hPa}$ (Liu et al., 2006). 
Atmos. Chem. Phys. Discuss., https://doi.org/10.5194/acp-2017-596

Table 1 - CERES and GEOS-FP low-cloud frequencies in the Southeast US. ${ }^{1}$

\begin{tabular}{|l|c|c|c|c|}
\hline & \multicolumn{2}{|c|}{ CERES Low-Cloud } & \multicolumn{2}{c|}{ GEOS-FP Low-Cloud } \\
\hline & Fraction & Optical Depth & Fraction & Optical Depth \\
\hline Cumulus & $11 \%$ & 1.6 & $<1 \%$ & 1.3 \\
\hline Stratocumulus & $9 \%$ & 8 & $6 \%$ & 13 \\
\hline Stratus & $1 \%$ & 36 & $3 \%$ & 31 \\
\hline
\end{tabular}

${ }^{1}$ Data from August-September 2013 for the domain of Figure 4. The classification of low-cloud type is done by CERES according 5

to optical depth below $680 \mathrm{hPa}$ : cumulus (0.02-3.55), stratocumulus (3.55-22.63), and stratus (22.63-378.65).
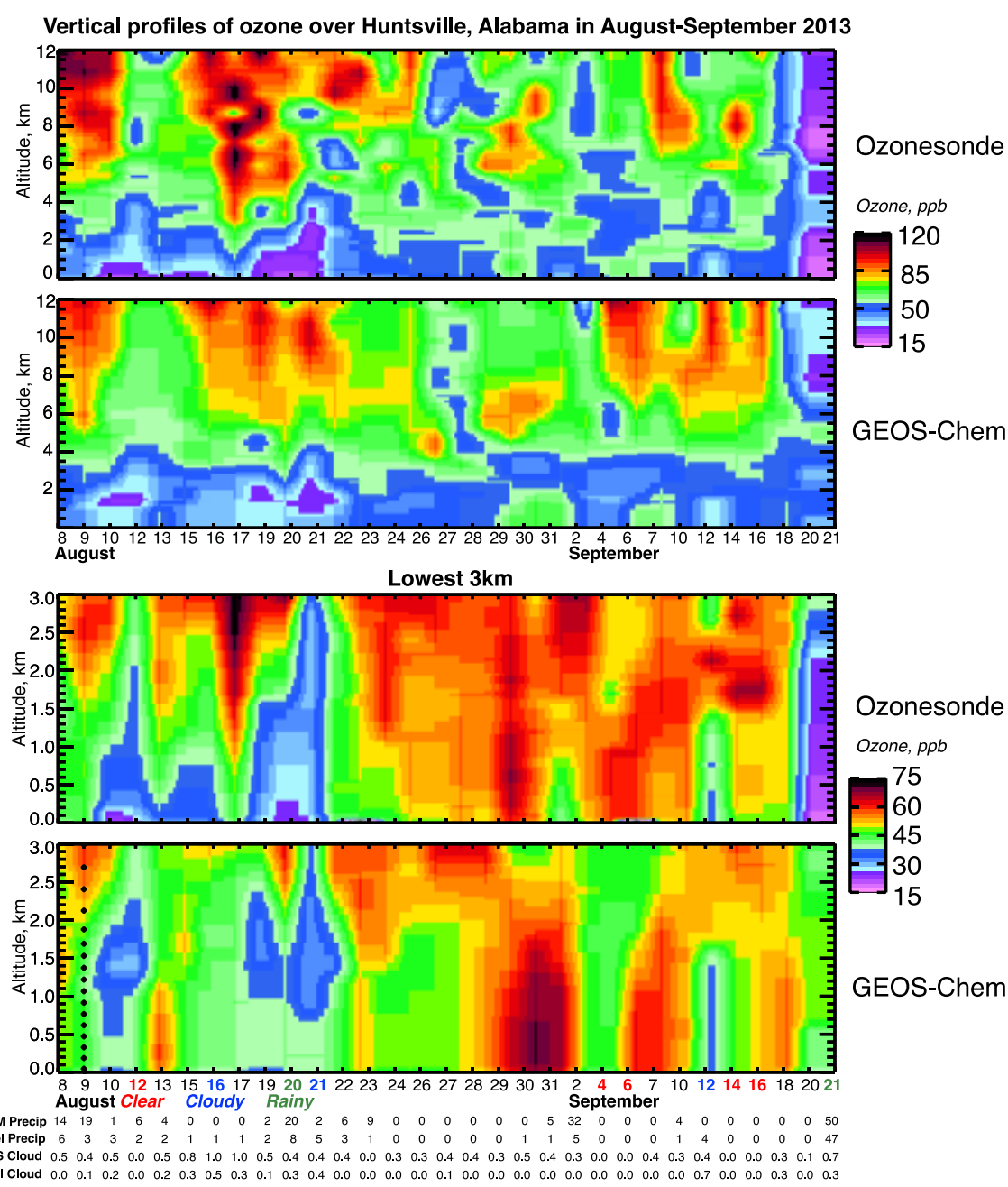

Figure 5 - Midday vertical profiles of ozone over Huntsville, Alabama ( $35.3 \mathrm{~N}, 86.6 \mathrm{~W}$ ) for the full troposphere (up to $12 \mathrm{~km}$, top) and for the PBL (up to $3 \mathrm{~km}$, bottom). Ozonesonde observations ( $n=31$ during 08 August -21 September 2013, launched at 10-13 local time) are compared to GEOS-Chem model profiles sampled at the same location and times. Values are interpolated in time between launches and are not intended to

10 resolve the diurnal cycle of ozone. The ASOS low-cloud fraction at the time of the ozonesonde launch and daily PRISM precipitation ( $\left.\mathrm{mm} \mathrm{d}^{-1}\right)$ are also shown along with the corresponding model values. Clear, low-cloud, and rainy days following the criteria of Section 4 are labeled in color in the abscissa. The black diamonds on the bottom plot show midpoints of the model grid levels. 


\section{Clear day: Sep 4}
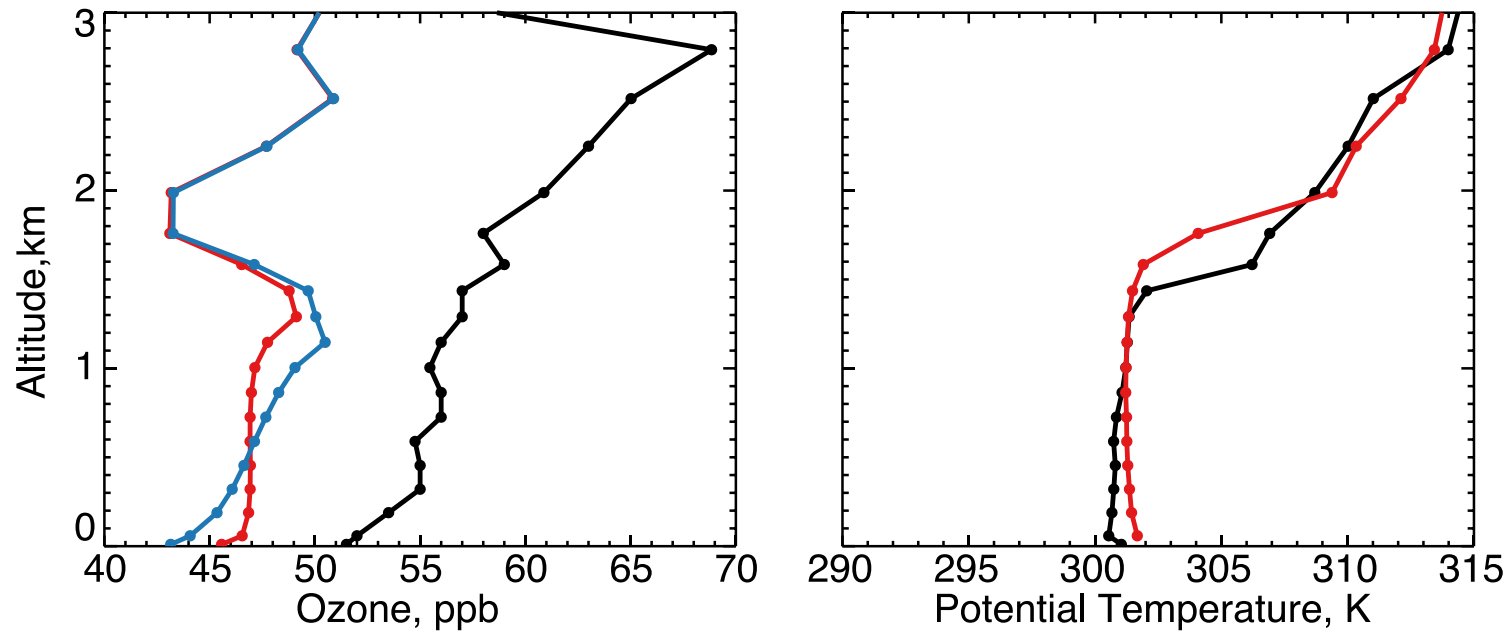

Cloudy day: Aug 16
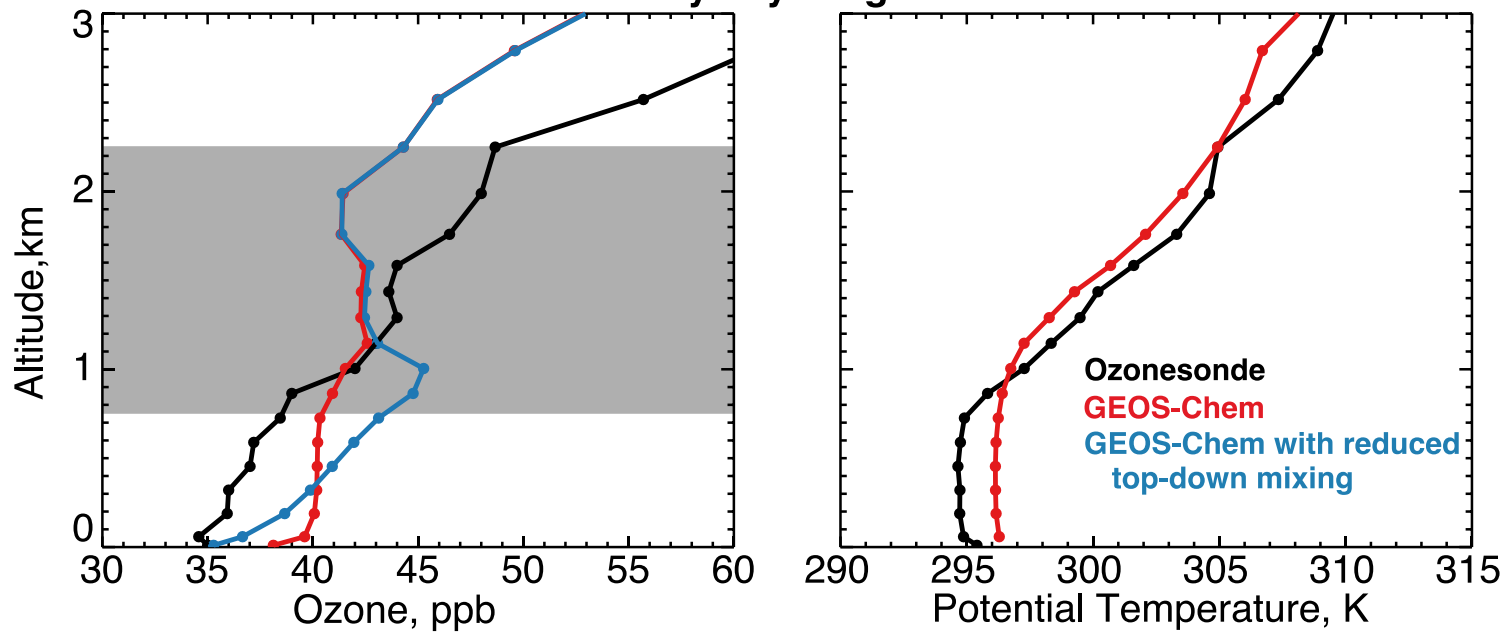

Figure 6 - Vertical profiles of ozone concentrations and potential temperature at the SEACIONS Huntsville site on representative clear-sky and low-cloud days from the record of Figure 5. The left panels include the sensitivity simulation with reduced top-down mixing in the mixed layer as described in Section 5. The grey shading in the bottom left panel indicates the cloud vertical extent as diagnosed from the ozonesonde relative humidity measurement. 